Article

\title{
Forming "Mediators and Instruments of Grace": The Emerging Role of Monastics in Teaching Contemplative Ambiguity and Practice to the Laity
}

\author{
Paula Pryce \\ Department of Anthropology, University of British Columbia, Vancouver, BC V6T 1Z1, Canada; pdpryce@ubc.ca \\ Received: 5 June 2019; Accepted: 24 June 2019; Published: 27 June 2019

\begin{abstract}
Drawing from long-term ethnographic research with a global network of contemplative Christians, this paper discusses an emerging teaching role for North American monasteries as the numbers of avowed religious decline. Since the Trappist community of St. Joseph's Abbey in Spencer, Massachusetts, first developed the Christian meditation technique called Centering Prayer in the 1970s, monks and nuns have increasingly become teachers, models, and stabilizers of non-monastic practitioners who attempt to transform their ways of being and thinking towards monastic-inspired sensibilities. Their guidance includes the use of face-to-face, literary, and virtual means to teach methods of contemplative intersubjectivity and a commitment to lives based on service, hospitality, and humility, as well as on study and formalized rites. The paper focuses on non-monastics' strong attraction to monastic teachings on ambiguity as a source of creativity and wonder in uncertain times, as practiced through a combination of cataphatic and apophatic ritual, including Centering Prayer. The number of monastic postulants continues to falter, yet a much larger, "non-gathered" community of non-monastic oblates and neo-monastic contemplatives has grown increasingly reliant on monastics to help provide alternatives. The rising interdependence of monastics and non-monastics may become the basis of a transformation of Christian monasticism and a new concept of religious community.
\end{abstract}

Keywords: religious pluralism; religious ambiguity; contemplative Christianity; lay contemplatives; monasticism; spiritual formation; Centering Prayer

Everything depends on maintaining and strengthening the communion we have with God in Christ. We bear fruit by remaining connected to Jesus, just as he bears fruit through his connection with the Father. We are not the originators of the divine grace that comforts and heals and saves; we are simply mediators and instruments of this grace.

-Br. David Vryhof, SSJE ${ }^{1}$

Many lay people in my anthropological research on the global network of Centering Prayer had at one time given up on Christianity. They sometimes spent years following other religions, particularly those that emphasize unity with the divine. However, sometime into their inter-religious sojourns, these people stumbled upon ancient and current-day contemplative expressions of Christianity and thus began renewing a relationship with the religious traditions into which they were born. Contemplative

1 This quote comes from the online platform, "Brother, Give us a Word", of the Cambridge, Massachusetts Episcopal monastery, The Society of Saint John the Evangelist (SSJE). Offered online or in email format, "Brother, Give Us a Word" is a daily lesson inspired by the fourth-century Desert Fathers' practice of mentoring by giving a single word on which novices could contemplate. See www.ssje.org. 
Christianity, ${ }^{2}$ an imperfect term I use to describe monastic-inspired, immanence-oriented forms of Christian ideals and practices, has become particularly attractive to a growing sector of spiritually devoted people who see human knowledge, and especially culturally specific religious knowledge, as inadequate in the face of a vast, largely unknowable universe. Rather than clinging to the parochial religious views they felt they had learned in childhood or abandoning religion altogether, these lay contemplatives have responded to the precarity and ambiguity of globalization with hospitable gestures of wonder and openness. The combination of monastic practice-oriented stability and the fluid, exploratory character of mystical ontology has become a resource for lay people who desire a connection with the divine, other humans, and all creation in the context of potentially unsettling religious, political, and cultural complexities of the contemporary pluralistic era. Albeit of a distinctive character, these people's desire for religious alternatives, including rigorous practices and sophisticated epistemologies, constitute one more example in a long history of American religious revivalism and enthusiasm (Roof 2001; Schmidt 2012; Schmidt and Promey 2012).

Some monastic communities have responded to this nascent contemplative Christian religious movement by offering formation adapted especially for lay people. Included are teachings on the value of humility in societies driven by achievement and acquisition, the discernment of a personal rule of life, and the practice of kenosis or self-emptying in Centering Prayer. Monastic instruction on ambiguity as an esteemed and necessary part of spiritual maturity goes further, however: silence, formalized rites, discipline, and service to others all work together to intentionally cultivate "unknowing" as a means to invite the divine into their midst. A lay desire for the nuanced and difficult lessons of Christian contemplation thus reveals a blossoming role for monks, nuns, and mendicants, even though their numbers continue to decrease. Especially in a globalized context in which they use digital media to teach beyond the physical walls of their cloisters, many avowed religious have become mentors on moral, philosophical, and phenomenological alternatives to a far-reaching network of lay contemplatives, drawing from ancient monastic disciplines to help their students become "mediators and instruments of ... grace" in an uncertain and rapidly changing world.

Beginning in 2009, my anthropological research of the vast global Centering Prayer network includes both monastic and non-monastic practitioners. Seeking to learn how this movement reaches across religious, social, and cultural boundaries, I have undertaken long-term, multi-sited participant observation research in monasteries, retreat centres, ashrams, zendos, and among numerous diverse religious organizations in the United States, Canada, the United Kingdom, Italy, Palestine/Israel, France, and South India. I have also learned from individual practitioners, who have written journals for me on their efforts to live as solitary contemplatives in otherwise ordinary communities, and I have followed the interactions, rituals, and teachings of online virtual communities. My book, The Monk's Cell: Ritual and Knowledge in American Contemplative Christianity (Pryce 2018), details my extensive ethnographic research, especially on the teaching relationships between the avowed religious and lay people in the American arm of The Centering Prayer network.

One American teacher of Centering Prayer has described her students as "broken-hearted Christians", lovers of the divine who say they could not abide the narrow-mindedness and banality they felt they had encountered in their childhood parishes (Bourgeault 2004). ${ }^{3}$ Frequently university educated and of the middle and upper-middle classes, their increasing knowledge has prompted these

2 My use of the term, "contemplative Christianity", is inadequate shorthand for a wide-ranging and diverse genre of Christianity that emphasizes divine immanence and connectedness, and focuses on enstatic practices, like silence, chant, lectio divina, and meditation. Many cloistered and semi-cloistered Christian monastic communities fall into this category. An increasing number of self-identified non-monastic Christians in the Western hemisphere find themselves feeling more connected to the contemplative aspects of other religions and have thus often drawn from the mystical texts and enstatic practices of both Christianity and other religions (Pryce 2018). This inter-religiosity is not unknown among monastics, as is clear from the writings of Merton $(1965,1968)$ and Thomas Keating's instigation of the annual Snowmass Conference, which has for decades brought together spiritual teachers from the world's "wisdom traditions" (Miles-Yepez 2006).

3 Rev. Dr. Bourgeault $(2008,2016)$, a well-known non-monastic Episcopal priest, author, and retreat leader, was trained among the American Trappist monks at St. Benedict's Monastery in Snowmass, Colorado, who developed Centering Prayer, 
seekers to steer away from easy answers and yet (despite some secularization theorists' predictions that such a demographic would reject religion (Berger 1967, 1999; Finke and Stark 2005), they continued to yearn for the divine. Such people often spend a great deal of time learning the practices and philosophies of religions like Buddhism, Sufism, Hinduism, and Judaism (Beneke 2006; Pryce 2018; Tipton 1982). Sometimes years later, they discovered that Christianity had its own enstatic, immanence-oriented traditions. By word of mouth and personal research, such as online searches, local lectures, and printed literature, some discovered, often to their astonishment, that Christianity also has a deep history of contemplative theologies and practices. Many individuals in my research told me that their childhood experiences gave them no inkling that some kinds of Christianity downplayed stringent doctrine and unyielding belief in favour of an emphasis on mystery and experiential communion through the aesthetics and practices of formal rites and intentional living, the ora et labora of monasticism. A Christianity of silence, wonder, and humility, they said, seemed to have enough openness and breadth to cultivate love for one's neighbour in an unfathomably diverse universe. Although they did not always re-join institutional churches in any formal way (Ammerman 2014; McGuire 2008; Tickle 2008), the people in my research slowly rekindled their relationship with Christianity, frequently with the guidance of monastic teachers.

Often emphasized in the American monastic communities in my research, Christian expressions of the unknowability of God have resonated profoundly with this expanding pluralistic movement of non-monastic Christian contemplatives. These people's inclination toward socio-religious boundary crossing and openness drew them especially toward certain ancient Christian motifs of the mystery and ambiguity of the divine. The writings of Hadewijch of Brabant, for example, have become increasingly popular among this group. The thirteenth-century Beguine mystic paid homage to the paradoxical "Abyss of Omnipotence" in which the unknowability of God "cannot be put into words, since it is unspeakable" (quoted in Petroff 1986, p. 197). A seeming mirror from the current era, Maggie, a woman from the American Northeast in my ethnographic research, described divine ineffability as "that unknown place beyond what is." A Midwesterner, Eleanor said something comparable: "Communion with God is an opening out into nothing. It really is no thing, something other than thing" (emphasis original). Contemplatives in my research have often described the deepest point of union with the divine as boundlessness and nothingness, which nevertheless confers what they have called "experiential knowledge."

Boston College philosopher Richard Kearney (2010) has attempted to understand this contemporary outward-looking interest in ambiguity among people who seek to dwell at ease with sociocultural pluralism and religion. He coined the term, anatheism, for the lived theology of people, like those in my ethnographic research, who have abandoned the triumphalism of a Christian-centered universe in favour of an hermeneutical posture that seeks to replace defensive certitude with humility. Kearney's anatheism, or "god after god", recognizes certain people's need to adjust their views of the divine in a world of immeasurable diversity, especially a world in which so many people suffer. Anatheists, wrote Kearney, are those who recognize the limits of their own knowledge. Yet rather than rejecting God in so uncertain and expansive a universe, they emphasize the need to welcome God in the stranger, thus taking on hospitality and openness as the central rubric in their stance of unknowing. Their primary intention is not to define a doctrinal list of facts and rules about the divine, but to extend hospitality and service to others. However, truly welcoming the other-listening and attempting to understand — can result in the destabilization of one's conceptual foundations, including established notions of the divine. A sincere engagement has required people to be open enough to make doctrinal tenets secondary and to try to perceive the universe without

including Fr. Thomas Keating. Bourgeault's far-reaching global ministry provides a formidable example of how monastics have had a powerful influence on the formation of non-monastic contemplatives.

4 Uncited quotations derive from my ethnographic fieldnotes or from the journals of interlocutors who wrote reflections especially for my research. 
preconception, which creates a world of increasing ambiguity. But in endeavouring to be open to a "stranger God" and to any stranger, wrote Kearney, they seek to create intimacy out of that ambiguity.

Like Kearney, Seligman and Weller (2012, p. 25) also see recent changes in religious observance, especially in ritual, as a response to the ambiguity born of the fast-paced globalization and virtual technologies of pluralistic societies. In their book, Rethinking Pluralism: Ritual, Experience, and Ambiguity, they note that repetition of ongoing, unending ritual cycles "allows us to live with ambiguity, not to remove it." Ritual is intrinsically relational, they wrote, emphasizing that ceremonial open-endedness itself is a gesture of hospitality. Seligman and Weller (2012, p. 98) said, "Accepting the world's discontinuities and ambiguities means that the world of building and refining relationships will never end. Ritual, at least in its relationship to the rest of experience, is never totally coherent and is never complete. Yet doing the work of ritual is one of the most important ways in which we live in such an inherently plural world." Indeed, ritual, especially the practice of silence, chant, and formalized liturgies with meanings that are not entirely clear, simultaneously offers constancy and fluidity. For people who shy away from the doctrinal certitude that conflicts with their desire to understand and accept human diversity, cataphasis, the active aspects of ritual, allow the stability of embodied action and repetition while at the same time opening immense space for reflection and interpretation, and even the cultivation of experiential ambiguity, or apophasis, which I will discuss further below (Pryce 2018, pp. 137-38; Louth 2012; cf. Luhrmann 2012, pp. 162-68).

\section{Why Monasticism?}

An orientation toward hospitality, service, and ritual is certainly not novel in Christianity, and is especially salient in Christian monasticism. To be sure, for many centuries Benedictine monasticism has formed itself around a rule of life based on a daily rhythm of prayer and work, as well as an imperative to greet the stranger as Christ in their midst (Benedict of Nursia 2011). Though perhaps seemingly ironic given the principle of monastic enclosure, the lived Benedictine tenets of hospitality, discipline, silence, and the formal rites of the Divine Office have become compelling for non-monastic contemplatives who are trying to embrace rather than reject a pluralistic world (e.g., Tomaine 2005). A contemporary re-orientation toward ritual and hospitality, now emerging out of people's desire for positive ways to address uncertainty and multiplicity, may explain a strengthening lay fascination with monasticism.

How have monastic communities responded to the upwelling? Some contemporary Christian monastics and mendicants have risen to the challenge by offering teachings on humility, hospitality, and a ritualized life which has recently become so attractive to a sector of the laity (e.g., Almquist 2008; Casey 2005; Chittister 2012; Funk 2001; Laird 2006; Rohr 2009; Smith 1989). While a teaching relationship between monastics and laity has a deep history (e.g., Baird 2006; McGinn 1994), rapid globalization and online communications have made convents and monasteries increasingly visible to people who may have previously had no contact or knowledge. Along with print media and the liturgies, workshops, and retreats they offer in their physical spaces, monastic communities have an increasing virtual presence. Through their own community websites and online platforms such as YouTube, they give lessons on monastic sensibilities, theologies, and practices which offer alternatives to more prevalent social norms. ${ }^{5}$ An added benefit for those in cloistered life, online forums allow monastics to teach while preserving their seclusion. Further, monastics are in a strong position to get their message across. They often have considerable social and cultural capital such as institutional

5 Just a few examples of websites of monastic communities and associated organizations include the Benedictine Sisters of Erie (www.eriebenedictines.org/, www.benetvision.org/, https://www.monasticway.org/, www.monasteriesoftheheart.org/), The Abbey of Regina Laudis (https://abbeyofreginalaudis.org/), The Center for Action and Contemplation (https://cac.org), The World Community for Christian Meditation (http://wccm.org/), Contemplative Outreach (www.contemplativeoutreach.org), the Anglican Benedictine Holy Cross Monastery (https://holycrossmonastery.com/), the Society of St. John the Evangelist (www.ssje.org), and the Monastery of Christ in the Desert (https://christdesert.org/). See Wagner (2012) for a study on virtual adaptations of religious practice and teaching. 
authority, formal education, social connections, creative approaches to ritual and various media, and rhetorical, diplomatic, and technical communication skills. Whether through online resources, print media, or real-space interactions, the current scale of teaching that has emerged from convents, monasteries, and associated organizations is unprecedented.

Monastic and mendicant teachers thus have an integral role in the growing global socio-religious movement of lay contemplative Christianity. My decade-long ethnographic research with The Centering Prayer movement illustrates this phenomenon. Centering Prayer is a form of Christian meditation developed some forty years ago by American Trappist monks as an accessible contemplative practice for lay people. Fr. Thomas Keating, a Trappist monk and well-known author who died in 2018, had noticed a surge in the burning desire of spiritual seekers in the United States beginning in the 1960s. The abbot of St. Joseph's Abbey in Spencer, Massachusetts, from 1961-1981, he wondered why so many young people passed by his monastery to stay at a nearby Buddhist temple, or travelled to places like India "to satisfy their hunger for an authentic spiritual path." He was puzzled that they did not turn to their own Christian religious traditions, which he knew had a deep history of contemplative teachings and practices that sought to foster intimacy between humans and the divine. Similar to the "broken-hearted Christians" whom I encountered in my own research, Keating found that many of these seekers were former Roman Catholics or Protestant Christians who had become skeptical about their own religious traditions. He learned that "many of them were disaffected from the religion of their youth because of the legalistic and overmoralistic teaching that many had received in their local parishes and Catholic schools; they now felt spiritually enriched [not by Christianity but] by their experiences in Buddhism and Hinduism." At that time in 1970s and 1980s America, most of the people to whom he spoke outside of the monastic environment did not even know of the great contemplative Christian traditions that spanned church history (Keating 2002, personal communication; pp. 11-12, 14-15).

Fr. Thomas Keating, Fr. William Meninger (1997), and the late Fr. Pennington (1983) were remarkably successful in their efforts to spread contemplative Christian ideas, practices, and sensibilities beyond the walls of their monastery through their development and teaching of Centering Prayer. These three Trappist monks essentially adapted Centering Prayer from the notion of kenosis or "self-emptying" in Philippians 2:5-8, the monastic practice of lectio divina, and the methods and ideas in a fourteenth-century English mystical text, The Cloud of Unknowing, whose monastic author (Anonymous 1961) recommends a prayer practice of cultivating "a naked intent to God" through the use of a sacred word. Keating describes the main principles of Centering Prayer as "consenting to the divine" by letting go of any thought or sensation that causes one to bring the mind into focus. Slightly different from many other meditation techniques, the transformational quality of Centering Prayer rises from alertness, consent, and self-emptying, say teachers, rather than from attention on a mantra, breath, or image. Centering Prayer is thus less a discipline of concentrated focus than it is a repeated ritualized release of thought and sensation. Ambiguity and emptiness are the main drivers of the practice.

Despite some institutional hesitancy (e.g., Ratzinger 1989), Centering Prayer now enjoys a global reach that has expanded well beyond the confines of Roman Catholicism. With innumerable books, retreats, and teaching forums on the practice, as well as an online organization called Contemplative Outreach which, at the time I published The Monk's Cell (Pryce 2018, p. 296), was serving 120 international chapters in 39 countries, supporting over 800 prayer groups in the United States alone, teaching the methods of Centering Prayer to 15,000 newcomers annually, and sending out 40,000 digital monthly newsletters. In addition, Contemplative Outreach had thousands of followers on Twitter and on the Facebook pages of local chapters. Centering Prayer thus brilliantly demonstrates the potential of monastic communities' outreach to religious seekers who hunger for openness and ways to address the divine in uncertain times. Centering Prayer has become a resource to address pluralism and a world of shifting categories, helping to satisfy the growing non-monastic desire to 
foster creative ambiguity through ritualized practices. The expansion of its network shows well the kind of impact monastics can have on the formation of laity.

The Centering Prayer movement is but one of numerous pedagogical threads emanating from monastic communities, however. My research has investigated these teaching relationships through the online platforms of large associations like Contemplative Outreach and at smaller-scale endeavours, like the face-to-face liturgies, workshops, and retreats in religious communities with local non-monastic congregations. Whether they use live, print, or virtual media, the monks, nuns, and mendicants with whom I have worked have attempted to guide the laity with alternative ideals, practices, and sensibilities that prize communality and ambiguity over acquisitiveness and achievement. American monastic teachers in particular are forthright in their perspective that their country is strongly influenced by individualistic, status-centered cultural values that need to be understood, critiqued, and transformed. For example, well-known Benedictine nun, teacher, and author Chittister (2012, p. 116) described her view of prevalent American ideals in this way: "Get money, the culture demands. Or power. Or prestige, at least. Get the trappings of the good life, the rumor of the great life, the reputation of success, the culture says, and that will be enough. But", she then asserted, "it isn't." Joan Chittister and many other nuns, monks, and mendicants have spent considerable energy trying to teach the hospitable, open-minded alternatives that they feel Christian monasticism has to offer.

How do monastics support their students in re-visioning a way of being and thinking that is both hospitable and challenging to acquisitive- and achievement-oriented mores? Let me turn to the principle of monastic humility as an example, a key ideal in contemplative Christianity that is related to kenosis or self-emptying, the technique that underlies the practice of Centering Prayer. Monastic teachers have understood that, particularly in North America, humility is one of the most difficult monastic principles for non-monastics to learn and to sustain. An essay on the principle of humility from Monastic Wisdom, a monthly digital teaching of the Cambridge, Massachusetts Episcopal monastery, the Society of Saint John the Evangelist (SSJE), shows how monastics attempt to reform prevalent cultural perspectives. Set in an appealing, aesthetically minimalistic webpage, the article addressed a common perception of humility in North America. The author, Br. David Vryhof, SSJE, wrote,

humility has gotten 'bad press' in the modern era. Too often it has been associated with passivity, complacency, and unquestioning submission to those in authority. When we think of humility, we are likely to conjure up images of persons with low self-esteem; people with fawning, weak personalities; or people who are afraid to assert themselves. Modern Western culture is rightly suspicious of that kind of 'humility' because it denies our intrinsic worth as human beings. ${ }^{6}$

In contrast to his assessment of common American cultural views, Br. David Vryhof sets out a different perspective by framing humility as a "truth that leads to freedom" and "a way of life that has been highly prized ... in Christianity", especially "in the Christian monastic tradition." Taking scriptural depictions of Jesus as his model, he relates the practice of humility to kenosis, the vulnerable self-offering that has drawn many non-monastics to contemplative Christianity. He wrote, "Consider the humility with which [Jesus] came to us, how he 'emptied himself, taking the form of a slave, being born in human likeness. And being found in human form, he humbled himself ... ' (Phil 2:7-8)." Br. David Vryhof thus encourages an understanding of humility as "a healthy balance between proper self-esteem —-based on the knowledge that we are beloved children of God who are made in God's own image —and an honest awareness and acceptance of our limitations, weaknesses and faults." Clearly both hospitable and pluralistic in his tone, Br. David Vryhof reaches back to the writings of the Desert Fathers to describe humility as an ancient means of "finding one's place in right relation to God and

6 Quotations from Br. David Vryhof's teachings on humility are from the Society of Saint John the Evangelist webpage, www.ssje.org/monasticwisdom/humility, accessed 25 March 2019. 
neighbor, without being swayed by the need for attention or praise or honor or power." Humility, he wrote, prompts "living peacefully and gently with others. Its two chief characteristics were a willingness to learn from others ... and a refusal to judge others" (emphasis in original). Having thus worked to revise his readers' understandings of humility, Br. David Vryhof then gives suggestions on how to integrate humility into daily life, offering inspiring quotations, questions for reflection, a list of more extensive resources, and pragmatic, easy-to-do exercises to help ground his readers' new-found knowledge.

This online monastic teaching on humility from the Society of Saint John the Evangelist is a tiny example of the plethora of resources currently available from American convents and monasteries. Many monastic teachers understand that in a complex, mobile society like the United States with its dizzying array of potential lifeways, learning and developing alternative ideals, practices, perceptions, and sensibilities is a long-term and often arduous endeavour that requires concerted intention, agency, and discipline. The monastics in my research were well aware of how difficult the adoption of contemplative lifeways was for people dwelling outside of the stabilizing force of a communal religious life. Finding the means to anchor themselves could be especially elusive for well-educated lay people who critiqued doctrine, theology, historical representations, and the authority of religious institutions. Many of the monks and nuns in my research did not expect their students to become formal adherents or to set aside their questions. Instead, they honoured the quandaries associated with doubt, recognized the frailty of human knowledge (even among the intellectually learned), and emphasized divine mystery. These teachers urged a greater reliance on regular, disciplined practice than on either iron-clad adherence to doctrinal belief systems or the volatility of emotion-centered spirituality.

Given the steadying effects of regularity, rhythm, and repetition, monastic teachers have tried to persuade their students to develop and follow rules of life adapted for non-monastics, including a schedule of prayer and work and service to others. Keeping a rule outside of monastic communities is not that straightforward, however, especially when discipline is dependent on the will of individuals with little social structural support. Importantly, keeping a rule implies that a dedication to practice and service is more important than emotion. In an American context in which self-expression and sentiment are primary cultural modes (Hall and Lindholm 1999; Bellah et al. 1985), committing to a scheduled rhythm regardless of how one feels was a steep learning curve for non-monastics, and indeed, my research found that many struggled to follow through in the long term (Pryce 2018, pp. 52-53). We can see the predicament in the words of a man who had been trying to establish his life as a non-monastic contemplative. At a lay retreat in an American Midwestern Benedictine monastery, he said in despair, "I am not up to this. This spiritual work demands more of me than I can do. I just can't do it" (Bauman 2013). Roger, a man from the American Southwest, gave me a similar story: "I've been trying to keep a contemplative life for years. I really feel called to it! I keep tinkering, trying to get it right. But sometimes I find I just can't keep at it when everyone else around me is zoning out on their phones or whatever. It's so hard when you're the only one." Yet those who persisted learned that a disciplined (but realistic) schedule of practice was more dependable in helping one keep ideals than was a desire for emotional equilibrium or a euphoric sense of connectedness to the divine, which teachers believed could manifest as an unmitigated self-centered drive for spiritual experiences and status.

Let us return to the Society of Saint John the Evangelist for an illustration of monastic efforts to stabilize lay people through teachings on rules of life. The SSJE community has published a number of print and online resources that assist their non-monastic adherents in creating personal rules of life that are idealistic yet pragmatic enough to be realizable. ${ }^{7}$ Their booklet Living Intentionally explains

7 The Society of Saint John the Evangelist clearly has a commitment to helping non-monastics develop and adopt rules of life. In addition to Living Intentionally, this community has also made available print, online, and audio-recording versions of their monastic rule (SSJE 1997; https://www.ssje.org/worship/rule-of-life-resources/) and has published a smaller rule written specifically for their formal association of oblates, The Fellowship of Saint John (SSJE n.d.b; http://www.ssje.org/fsjrule/). Further, they have produced a number of other resources, including a video series called A Framework for Freedom and, 
that, rather than being a restrictive list of uncompromising dictates, "rule" in the monastic context comes from the Latin regula, a word that suggests "a way of regularizing our lives so that we can stay on the path we have set out for ourselves. A rule is like a trellis which offers support and guidance for a plant, helping it to grown in a certain direction." The monks taught that the central purpose of a rule was "to live our lives for God with purpose and intention." It could be prescriptive, outlining daily practices and social responsibilities, and could also describe and identify the foundational principles and philosophies that underlie one's desire to live an intentional life. Particularly for those attempting to follow a contemplative life without the everyday support of a monastic community, SSJE members "strongly recommend [keeping a rule] simple, ... realistic and achievable ... Like any spiritual discipline, adopting a rule should help one to live more faithfully" rather than make life more difficult (SSJE n.d.a, emphasis in original).

An example of a lay person who chose to adopt a disciplined schedule of practice, a man named Andrew told me how monastic methods had become a tool to reinforce his intentions. Having learned some practical strategies from monastic teachers over the fifteen years he had been practicing Centering Prayer and other contemplative techniques, Andrew said during a period of instability when his marriage had broken up and he had moved far from family and friends for a new job, "For the aspects of my contemplative life that aren't going the way I want them to, I know the answer is to put them on my schedule and follow through with them. Not in an unbending way, but in a 'this is what I want and I'm going to give myself these gifts' way." Andrew's perspective was that monastic-style discipline had bolstered his voluntary choice to follow a contemplative lifestyle.

Perhaps paradoxically, monastic guidance on discipline through rhythm and repetition of work, prayer, and service offered non-monastic contemplatives a route to the creative ambiguity they so deeply craved. Ritualized forms, like Centering Prayer and intentional work, can provide a subjunctive framework that helps practitioners negotiate the indeterminate realities of both pluralized societies and an unknowable God. Seligman and Weller (2012, p. 93) described ritualized structures as "a unique human resource for dealing with ambiguity and the multivocal nature of all relationships-with beings human and divine." They added that ritual "presents a coherent and embracing way to live in a plural and hence also deeply ambiguous universe, one where order can never really be known, but still must be acted upon." In contrast to a dependence on the hard-edged belief and ephemeral emotion found in some manifestations of Christianity, regularized rites and a ritualization of everyday life provide a structure in which contemplatives can learn to address the uncertainty that particularly abounds in the shifting diversity of the contemporary world.

Learning to live with the sociocultural and religious precarity of globalization and pluralism was certainly not ritualization's only selling point for non-monastics, however. They have also used ritual to intentionally cultivate apophasis or "unknowing" as a path to intimacy with the divine and all creation. Contemplative Christians in my research, both monastics and their non-monastic students, used the shelter of repetitive cataphatic practices like Centering Prayer, the canonical hours, lectio divina, and intentional labour to foster union with the divine through the inner gestures of consent, kenosis, and self-emptying. As one teacher in my research described it, ritual is a "strong container" that allows a safe haven for apophatic exploration of an unknown universe. A regularized, stable practice, enacted regardless of sentiment, can craft potent, creative environments of experiential and intellectual ambiguity that foster a refinement of senses and an ability to hear and see in new ways.

Some of the lay practitioners in my ethnographic research learned well their lessons on unknowing. For instance, Elizabeth, an addictions counsellor from the Northeast region of the United States, described how her desire for intimacy with the divine had prompted her to patiently develop a

co-produced with the Center for the Ministry of Teaching at Virginia Theological Seminary, a community workshop program called Growing a Rule of Life: Relationship with God, Self, Creation, and Others, which includes a paper and online workbook and an online participation page (Framework for Freedom: http://www.ssje.org/framework\%20for\%20freedom/; Growing a Rule of Life: (https://www.ssje.org/growruleresources/). 
Centering Prayer practice over a decade. She worked hard to follow monastic guidance on being faithful to a daily rhythm of two periods of meditation a day whether she felt any positive effects or not. Elizabeth said to me,

I've learned that you can't do Centering Prayer because someone else says you should, or because you happen to feel like it, or because you want a good 'trip'. After all these years, I can see that sitting [and meditating] does something I might not be able to understand in the moment. It's a weird combination of doing something and doing nothing. I have to trust it ... Often enough, I find myself really letting go and entering that beautiful cave. I'm just sitting there and the universe opens up. I just keep practicing and sometimes nothing turns into something, or something turns into nothing, and I feel the flow of God.

Reflecting on the words of people like Elizabeth, we see that monastic communities have a clear and explicit role in mentoring formerly disillusioned lay people who have returned to Christianity after discovering its contemplative dimensions. Under the tutelage of their monastic teachers, lay contemplatives have begun to find steady ground in a volatile world. Monastics in my research used a variety of print and virtual media, as well as face-to-face encounters, to direct non-monastics towards a framework of practices and ideals that help temper the potential capriciousness of the contemplative arts. Their tools-like keeping a personal rule of life, subscribing to a daily rhythm of work and prayer, and acting in the service of others-were contemporary adaptations of historical Christian monastic disciplines, particularly those modelled on the fifteen-hundred-year-old Benedictine tradition. Curiously, many lay people felt that the firmness of monastic discipline, schedules, and formalized rites allows an intellectual and ontological liberty to explore beyond the limiting strictures of socio-religious world views. For anatheistic Christians who have a strong desire for the divine and an honest interest in connecting with people across cultural and religious barriers, the monastic pairing of cataphatic structure and apophatic freedom is deeply attractive. Christian non-monastics in my research were especially drawn to the uncertain meanings of monastic ritual, mystical texts, and silence, which seemed to reflect the ambiguity of both a pluralistic universe and the limits of human knowledge, while nevertheless providing enough stability to meander through a universe beyond imagining. By honouring and cultivating the unknown through ritual practice and alternative ideals, these Christian contemplatives invite an hospitable surrender and a connectedness with "the stranger", whether human or divine.

Funding: This research received funding from the Social Sciences and Humanities Research Council of Canada and The Louisville Institute.

Conflicts of Interest: The author declares no conflict of interest.

\section{References}

Almquist, Curtis G. 2008. Unwrapping the Gifts: The Twelve Days of Christmas. Lanham: Cowley.

Ammerman, Nancy Tatom. 2014. Sacred Stories, Spiritual Tribes: Finding Religion in Everyday Life. New York: Oxford University Press.

Anonymous. 1961. The Cloud of Unknowing and Other Works. Translated by Clifton Wolters. London: Penguin.

Baird, Joseph L. 2006. The Personal Correspondence of Hildegard of Bingen. Oxford: Oxford University Press.

Bauman, Ward. 2013. Episcopal House of Prayer Newsletter. Collegeville: Episcopal House of Prayer.

Bellah, Robert, Richard Madsen, William Sullivan, Ann Swidler, and Steve Tipton. 1985. Habits of the Heart: Individualism and Commitment in American Life. Berkeley: University of California Press.

Benedict of Nursia. 2011. The Rule of Saint Benedict. Translated and Edited by Bruce L. Venarde. Cambridge: Harvard University Press.

Beneke, Christopher J. 2006. Beyond Toleration: The Religious Origins of American Pluralism. New York: Oxford University Press.

Berger, Peter L. 1967. The Sacred Canopy: Elements of a Sociological Theory of Religion. New York: Anchor Books. Berger, Peter L. 1999. The Desecularization of the World: Resurgent Religion and World Politics. Grand Rapids: Eerdmans. 
Bourgeault, Cynthia. 2004. Centering Prayer and Inner Awakening. Cambridge: Cowley.

Bourgeault, Cynthia. 2008. The Wisdom Jesus: Transforming Heart and Mind-A New Perspective on Christ and His Message. Boston: Shambhala.

Bourgeault, Cynthia. 2016. The Heart of Centering Prayer: Christian Nonduality in Theory and Practice. Boston: Shambhala.

Casey, Michael. 2005. Strangers in the City: Reflections on the Beliefs and Values of the Rule of St. Benedict. Brewster: Paraclete Press.

Chittister, Joan. 2012. Following the Path: The Search for a Life of Passion, Purpose, and Joy. New York: Crown.

Finke, Roger, and Rodney Stark. 2005. The Churching of America, 1776-2005: Winners and Losers in Our Religious Economy. New Brunswick: Rutgers University Press.

Funk, M.M. 2001. Tools Matter for Practicing the Spiritual Life. New York: Continuum.

Hall, John A., and Charles Lindholm. 1999. Is America Breaking Apart? Princeton: Princeton University Press.

Kearney, Richard. 2010. Anatheism: Returning to God after God. New York: Columbia University Press.

Keating, Thomas. 2002. Intimacy with God: An Introduction to Centering Prayer. New York: Crossroads.

Laird, Martin. 2006. Into the Silent Land: A Guide to the Christian Practice of Contemplation. New York: Oxford University Press.

Louth, Andrew. 2012. Apophatic and Cataphatic Theology. In The Cambridge Companion to Christian Mysticism. Edited by Amy Hollywood and Patricia Z. Beckman. Cambridge: Cambridge University Press, pp. 137-46.

Luhrmann, Tanya M. 2012. When God Talks Back: Understanding the American Evangelical Relationship with God. New York: Alfred A. Knopf.

McGinn, Bernard. 1994. Meister Eckhart and the Beguines in the Context of Vernacular Theology. In Meister Eckhart and the Beguine Mystics. Edited by Bernard McGinn. New York: Continuum, pp. 1-14.

McGuire, Meredith. 2008. Lived Religion: Faith and Practice in Everyday Life. New York: Oxford University Press.

Meninger, William A. 1997. The Loving Search for God: Contemplative Prayer and the Cloud of Unknowing. New York: Continuum.

Merton, Thomas. 1965. The Way of Chuang-Tzu. New York: New Directions.

Merton, Thomas. 1968. Zen and the Birds of Appetite. New York: New Directions.

Miles-Yepez, Netanel, ed. 2006. The Common Heart: An Experience of Interreligious Dialogue. New York: Lantern Books.

Pennington, Basil. 1983. A Place Apart: Monastic Prayer and Practice for Everyone. Garden City: Doubleday.

Petroff, Elizabeth Avilda. 1986. Medieval Women's Visionary Literature. Oxford: Oxford University Press.

Pryce, Paula. 2018. The Monk's Cell: Ritual and Knowledge in American Contemplative Christianity. New York: Oxford University Press.

Ratzinger, Cardinal Joseph. 1989. Letter to the Bishops of the Catholic Church on Some Aspects of Christian Meditation. Congregation for the Doctrine of Faith. Rome: Vatican, October 15.

Rohr, Richard. 2009. The Naked Now: Learning to See as the Mystics See. New York: Crossroads.

Roof, Wade Clark. 2001. Spiritual Marketplace: Baby Boomers and the Remaking of American Religion. Princeton: Princeton University Press.

Schmidt, Leigh Eric. 2012. Restless Souls: The Making of American Spirituality. Berkeley: University of California Press.

Schmidt, Leigh Eric, and Sally M. Promey, eds. 2012. American Religious Liberalism. Bloomington: Indiana University Press.

Seligman, Adam B., and Robert P. Weller. 2012. Rethinking Pluralism: Ritual, Experience, and Ambiguity. New York: Oxford University Press.

Smith, Martin. 1989. The Word is Very Near You: A Guide to Praying with Scripture. Cambridge: Cowley.

SSJE (Society of Saint John the Evangelist). 1997. The Rule of the Society of Saint John the Evangelist. Lanham: Cowley.

SSJE. n.d.a. Living Intentionally: A Workbook for Creating a Personal Rule of Life. Cambridge: Society of Saint John the Evangelist.

SSJE. n.d.b. The Rule of the Fellowship of Saint John. Cambridge: Society of Saint John the Evangelist.

Tickle, Phyllis. 2008. The Great Emergence: How Christianity Is Changing and Why It Matters. Grand Rapids: Baker Books.

Tipton, Steven M. 1982. Getting Saved from the Sixties: Moral Meaning in Conversion and Cultural Change. Berkeley: University of California Press. 
Tomaine, Jane. 2005. St. Benedict's Toolbox: The Nuts and Bolts of Everyday Benedictine Living. Harrisbury: Morehouse. Wagner, Rachel. 2012. Godwired: Religion, Ritual, and Virtual Reality. New York: Routledge.

(C) 2019 by the author. Licensee MDPI, Basel, Switzerland. This article is an open access article distributed under the terms and conditions of the Creative Commons Attribution (CC BY) license (http://creativecommons.org/licenses/by/4.0/). 